\title{
Copepod grazing behavior in simulated natural light and its relation to nocturnal feeding
}

\author{
Donald E. Stearns \\ Duke University Marine Laboratory, Pivers Island, Beaufort, North Carolina 28516-9721, USA* \\ and \\ Skidaway Institute of Oceanography, P.O. Box 13687, Savannah, Georgia 31416-0687, USA *
}

\begin{abstract}
To investigate the role of light in controlling copepod grazing behavior, feeding responses of adult female Acartia tonsa Dana were determined under light conditions similar to those in natural, subsurface waters. Measured feeding responses were then related to feeding behavior under similar light conditions in nature. Copepods were adapted to a range of light intensities before being offered food (Thalassiosira weissflogii, $0.5 \mathrm{~mm}^{3} \mathrm{l}^{-1}$ ). Thirty min later gut contents were measured by gut fluorescence of chlorophyll $a$ and pheopigment $a$. The grazing index was inversely related to the light intensity at which the copepods were adapted. The most dramatic change in grazing occurred at light levels close to those found in the copepod's natural habitat during twilight. An endogenous nocturnal feeding rhythm was found in a separate experiment. A $96 \mathrm{~h}$ field study in the Newport River estuary, North Carolina, USA, revealed a nocturnal feeding pattern in $A$ tonsa and a negative correlation between feeding and light intensity during daylight hours. No significant correlations were found between copepod feeding and in situ concentrations of chlorophyll $a$, pheopigment $a$ and combined pigments. These results challenge Gauld's (1953) hypothesis that nocturnal grazing results from nocturnal vertical migration into a food-rich layer; they offer a reasonable explanation of how light may time grazing. Results indicate that migration and feeding may be independent behaviors separately controlled by light cues.
\end{abstract}

\section{INTRODUCTION}

Many grazing copepods increase their feeding at night relative to during the day (e.g. Daro 1980, Baars \& Oosterhuis 1984, Head et al. 1984, Mayzaud et al. 1984 , references cited therein). Given the apparently common occurrence of nocturnal feeding and its importance in determining grazing pressure and primary and secondary production within planktonic systems (Petipa \& Makarova 1969, McAllister 1971, 1973), it is important to understand how this behavioral phenomenon is timed.

A positive correlation between nocturnal feeding and nocturnal vertical migration led Gauld (1953) to hypothesize that copepods move vertically into and out of food patches, with nocturnal feeding the result of the copepods' location within patches of higher food concentration at night than during the day. According to Gauld's (1953) hypothesis, nocturnal grazers must be

\footnotetext{
- Facilities used for Newport River field study

- Facilities used for all other research; present address
}

nocturnal vertical migrators in a vertically stratified food environment. While many field studies support the hypothesis (Gauld 1953, Sushkina 1962, Petipa 1964 a, b, Zagorodnyaya 1974, Hart 1977, Daro 1980, Hayward 1980, Tande \& Slagstad 1982, Simard et al. 1985), many studies do not. Nocturnal feeding sometimes occurs in the absence of nocturnal vertical migration (Mackas \& Bohrer 1976, Peruyeva 1977, Boyd et al. 1980, Hayward 1980, Nicolajsen et al. 1983, Head et al. 1985). Nocturnal feeding has also been reported in a region where chlorophyll a was vertically homogeneous (Mayzaud et al. 1984). Petipa (1958) reported that Acartia clausi never leaves the phytoplankton-rich zone yet feeds nocturnally. Baars \& Oosterhuis (1984) found Pseudocalanus elongatus, Temora longicornis and Calanus helgolandicus to be nocturnal grazers. These species were collected throughout the water column and feeding periodicity could not be attributed to vertical migration within a vertically stratified food environment.

According to Gauld's (1953) hypothesis, increased feeding occurs with increasing food concentration. 
While most field and laboratory studies generally support this view, within food concentration limits (see review by Conover 1981), there is field and laboratory evidence that the 2 factors are not always positively correlated (Mackas \& Bohrer 1976, Cowles 1977, Boyd et al. 1980, Dagg \& Grill 1980, Hayward 1980, Dagg \& Wyman 1983, Kleppel \& Manzanilla 1983, Båmstedt 1984, Head et al. 1985, Kleppel et al. 1985). Dagg \& Grill (1980), who observed nocturnal feeding by female Centropages typicus in New York Bight, commented that the factors which restrict feeding during daylight hours when Centropages typicus females are surrounded by food and are ingesting less than a maximum daily ration must be strong'. While it is obvious that a copepod cannot feed without food, the timing of its feeding is not necessarily controlled only by food availability.

Nocturnal feeding in copepods may be under endogenous control. An endogenous, crepuscular feeding rhythm in a zooplankton assemblage composed primarily of Daphnia pulex and Cyclops scutifer, tested under conditions of constant darkness, was described by Duval \& Geen (1976). However, Gauld (1953), Richman \& Rogers (1969) and Hart (1977) found no evidence of an endogenous feeding rhythm in other copepods.

Light cues may control the timing of nocturnal grazing in copepods. Marshall (1924) anecdotally observed that even bright moonlight may inhibit feeding by Calanus finmarchicus, although she presented no supporting data. The same species feeds more in the dark than in the light (Fuller 1937, Marshall \& Orr 1955); so does Calanus helgolandicus (Richman \& Rogers 1969). During the Arctic summer when Calanus hyperboreus and Calanus glacialis are not nocturnally vertically migrating, these species are strong nocturnal feeders. The onset of nocturnal grazing appears related to a low light level (Head et al. 1985). By placing copepods in jars in an outdoor water bath and using screens to control light intensity, Fernández (1977) showed, for several species, an inverse relation between feeding and light intensity. However, he was unable to keep the light intensity constant throughout the incubation period of several hours, in part because of cloud cover and changing solar angle, in part because the jars were constantly rotated on a wheel immersed in the water bath. Also, no description was provided of the underwater angular light distribution (ALD), although this factor can affect copepod behavior (Schallek 1942 , 1943).

Although it is well known that Acartia tonsa Dana is an omnivore capable of feeding on phytoplankton, protozoans, metazoans and detritus (see review by Turner 1984b), field studies of in situ feeding in phytoplankton-rich, coastal environments indicate that the species feeds primarily on phytoplankton (Turner 1984a). To investigate the role of light in controlling copepod feeding behavior, grazing responses of the adult female copepod $A$. tonsa were measured in the laboratory under ALD conditions similar to those in natural, subsurface waters. An experiment was also completed to test for the presence of an endogenous feeding rhythm in adult female $A$. tonsa. Measured feeding responses were then related to feeding behavior in nature.

\section{MATERIAL AND METHODS}

General procedures for light experiments. Measurements were made of the feeding behavior of adult female Acartia tonsa exposed to different quantal light intensities. For experiments done at a laboratory temperature of $14.75^{\circ} \mathrm{C}$, plankton samples were collected at night from the surface of the Wilmington River estuary, Georgia, USA (field salinity range 22 to $30 \%$; field temperature range 13 to $25^{\circ} \mathrm{C}$ ). The plankton sample was aerated for 60 to $70 \mathrm{~h}$ in a temperaturecontrolled room under conditions used for the algal cultures (12:12 L : D photoperiodicity, $14.75^{\circ} \mathrm{C}, 34 \%$ ).

Feeding behavior was tested in an apparatus designed to simulate the natural underwater ALD pattern near midday (Fig. 1). The center of the reflected light field was positioned at the zenith with respect to the centers of the test chamber and the water bath, to ensure the same light pattern in all vertical planes. Although ALD changes with solar angle in nature, the experimental ALD was kept the same. Using a constant

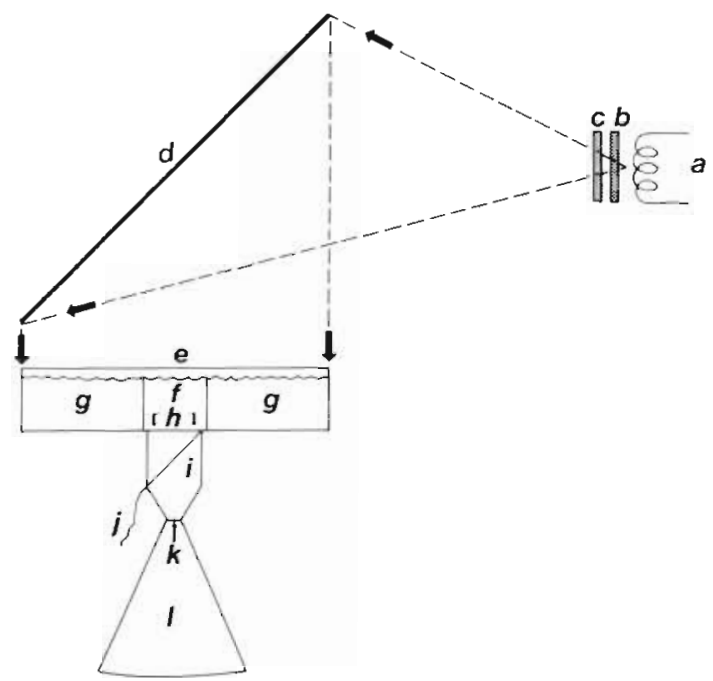

Fig. 1. Experimental apparatus for experiments testing for light effect on feeding behavior of adult female Acartia tonsa. a: light source; b: Corning 4-94 filter; c: neutral density filters; d: mirror; e: translucent plate; $\mathrm{f}$ : test chamber; g: water bath; h: trap door; 1 : PVC pipe; $j$ : thread; $k$ : filter ${ }_{i}$ l: filtration flask 
but realistically diffuse light pattern allowed comparisons of grazing behavior at different light adaptation levels while minimizing artifactual behavior that may have been elicited by using unnaturally directional light

Fig. 1 is a diagram of the experimental apparatus. The copepods were placed in a plexiglass test chamber $(10 \times 10 \times 10 \mathrm{~cm})$ positioned in the center of a much larger water bath $(50 \times 50 \times 10 \mathrm{~cm}$ high) with walls and bottom painted flat black. The walls of the bath were outside the critical angle (zenith $\pm 48.6^{\circ}$ ) as viewed from the bottom of the test chamber. The water surface of the test chamber was continuous with that of the water bath. Projectors fitted with $300 \mathrm{~W}$ tungstenfilament halogen lamps were used as light sources. A Sola ${ }^{\circledR}$ CVS constant voltage transformer was used to minimize fluctuations in quantal output. A Corning 4-94 filter (half band pass $=385$ to $565 \mathrm{~nm}$ ) was used to filter light to the spectral range of maximal sensitivity for Acartia tonsa (Stearns \& Forward 1984a). A lighttight partition prevented extraneous light from reaching the test chamber. The selected light beam expanded to a size larger than the water bath before being reflected over the bath by a mirror. Before entering the bath, the light beam passed through a translucent plexiglass diffuser. The ALD measured near the bottom of the test chamber was similar to that measured in estuarine water near midday (Fig. 2). The bottom of the bath had a small, circular window through which light intensity was measured during the experiments. Copepods were isolated on one side of a lighttight, temperature-controlled room, away from the light source, and noise and vibrations were kept to a minimum (see Buchanan et al. 1982).

Centered on the bottom of the test chamber was a circular opening (diameter $=89 \mathrm{~mm}$ ) covered by a piece of plankton netting dipped in flat black paint that occluded the meshes. A polyvinyl chloride pipe (inner diameter $=76 \mathrm{~mm}$ ) fit inside the circular opening and was connected to a 21 Millipore ${ }^{\circledR}$ filtration apparatus. Water level was maintained by plugging the stem of the filter support. The plankton netting functioned as a trap door that kept the copepods in the $1 \mathrm{l}$ test chamber until it was opened.

The ALD was measured underwater in the water bath at the bottom of the test chamber. White light was used and measurements were taken with a LI-COR LI192S underwater quantum sensor fitted with a Gershun tube (total acceptance angle $=17.5^{\circ}$ ) and connected to a LI-COR LI-185A quantum meter (Lambda Instruments). For simulation purposes ALDs were measured in the Skidaway River estuary, Savannah, Georgia, USA, near midday under clear skies near slack high tide, using a LI-COR LI-192SE sensor fitted with a Gershun tube (total acceptance angle $=20^{\circ}$ ) and con-

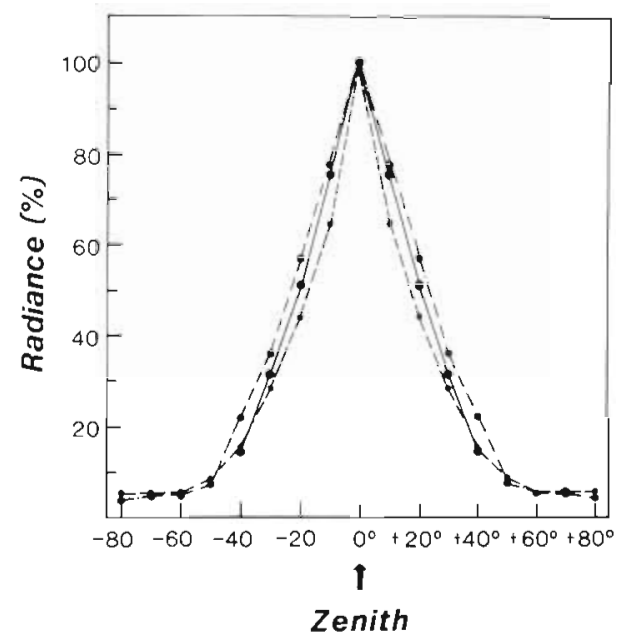

Fig. 2. Angular light distribution (ALD) comparisons. Radiant energy in the zenith direction $\left(0^{\circ}\right)$ is considered $100 \%$ and intensities at different angles from the vertical are shown. Solid line $=$ underwater ALD in water bath as measured at depth of bottom of test chamber. Approximately the same pattern was observed in all vertical planes because the light source was at the zenith. Field ALDs were measured in the Skidaway River estuary, Georgia, USA, under clear skies near slack high tide at $0.5 \mathrm{~m}$ depth (Aug 30, 1984, $1130 \mathrm{~h}$ Eastern Standard Time, dashed line) and at $1.5 \mathrm{~m}$ depth (Aug 29, $1984,1130 \mathrm{~h}$, dashed and dotted line)

nected to a LI-COR LI-185 quantum meter (Fig. 2). The lowering frame allowed for rotation of the sensor in a vertical plane.

For each experimental run, 30 copepods were sorted into a $100 \mathrm{ml}$ beaker half filled with $0.8 \mu \mathrm{m}$ Millipore ${ }^{\mathbb{R}}$ filtered sea water. After flushing the beaker 3 times to remove food the copepods were checked for damage using a dissection microscope and were then gently rinsed into the test chamber, which had previously been almost filled with Millipore ${ }^{\circledR}$ filtered sea water. The test chamber was then filled to the level of the bath water surface. After placing the translucent diffuser over the water bath, the copepods were left in darkness for $1 \mathrm{~h}$ to allow them to approach their level of maximal photosensitivity (Autrum 1981). The stimulus light was then turned on and the copepods were allowed to adapt to a selected intensity for $1 \mathrm{~h}$. The copepods were thus left undisturbed for $2 \mathrm{~h}$ before being tested in an effort to avoid the feeding problems found by Arashkevich (1975) which resulted from constant handling of Acartia tonsa.

After 1 h of light adaptation, food (Thalassiosira weissfloggi in log growth phase) was added to the test chamber using a curved pipette without removing the diffuser. Either Coulter Counter ${ }^{\circledR}$ Model TAII or ZB (Coulter Electronics, Inc.) was used to determine the volume of algal culture needed to provide a food concentration of $0.5 \mathrm{~mm}^{3} \mathrm{l}^{-1}$ inside the test chamber. Immediately after adding the food $10 \mathrm{ml}$ of air was 
bubbled throughout the test chamber to distribute the food. The light intensity was then measured with a LICOR LI-185A quantum meter fitted with the LI-190S quanturn sensor (Lambda Instruments).

After $30 \mathrm{~min}$ exposure to the food the trap door was opened, the stem of the filter holder was unplugged and the contents of the test chamber were filtered onto a $4.25 \mathrm{~cm}$ Whatman No. 1 paper filter using a vacuum pump set at $400 \mathrm{~mm} \mathrm{Hg}$ (filtering time $\sim 110 \mathrm{~s}$ ). The filter paper was immediately placed in a plastic Petri dish and frozen. The test chamber was rinsed thoroughly with distilled water between experimental runs.

Frozen copepod samples were examined under a dissecting microscope. The copepods were counted, transferred to a clean, $25 \mathrm{~mm}$ Gelman Type A/E glass fiber filter, ground in an ice bath with $10 \mathrm{ml}$ of $90 \%$ aqueous acetone and left in darkness for $24 \mathrm{~h}$, with periodic shaking, to extract the pigments. Each sample was then centrifuged and chlorophyll $a$ and pheopigment a were measured by fluorescence using a Turner Designs fluorometer (Model 10 series).

The general method was that of Yentsch \& Menzel (1963) as described by Strickland \& Parsons (1972), except that pigment concentration was divided by copepod sample size (21 to 30 ) instead of volume of water filtered. This fluorescence technique does not distinguish between pheophytin a and pheophorbide $a$; hence the term 'pheopigment $a$ ' includes both compounds. Total pigment (chlorophyll a + pheopigmenta) concentration per copepod was normalized for body size by dividing by cephalothorax length (mm). The length measurements (range $=0.81$ to $0.94 \mathrm{~mm}$ ) were obtained periodically on copepods collected with those used for experiments. Background fluorescence was similarly determined from copepods that survived being placed in $0.8 \mu \mathrm{m}$ Millipore ${ }^{\circledR i l t e r e d ~ s e a ~ w a t e r ~ f o r ~}$ $40 \mathrm{~h}$ before being filtered and frozen. Background fluorescence was similarly normalized for body size (mean background grazing index $=0.113$, $\mathrm{SE}=$ $0.0091, n=3$ samples of 27 to 30 copepods per sample), then subtracted from the total pigment concentration to estimate the pigment concentration that resulted from grazing.

In this manner, the feeding behavior of Acartia tonsa was measured under simulated natural light conditions, at light adaptation levels ranging from $0 \mu \mathrm{E}$ $\mathrm{m}^{-2} \mathrm{~s}^{-1}$ (dark controls) to $20.25 \mu \mathrm{E} \mathrm{m}^{-2} \mathrm{~s}^{-1}$ (' $\mathrm{E}$ ' represents einsteins). Projector wattage restrictions prevented testing at higher light levels. To determine how effective the higher experimental light intensities were in reducing feeding, 6 groups of copepods were treated similarly but without the addition of food to the test chamber. They were light-adapted to a quantal intensity of $19.6 \mu \mathrm{E} \mathrm{m}^{-2} \mathrm{~s}^{-1}$.
In addition to measuring feeding behavior at $14.75^{\circ} \mathrm{C}$, similar experiments were completed at experimental temperatures of 12 and $22.5^{\circ} \mathrm{C}$. For the $12{ }^{\circ} \mathrm{C}$ experiments, the copepods were collected within a field temperature range of 8.5 to $9^{\circ} \mathrm{C}$ and a salinity range of 28 to $29 \%$. For the $22.5^{\circ} \mathrm{C}$ experiments, the field temperature was $22.5^{\circ} \mathrm{C}$ and the salinity range was 24 to $27 \%$. For each of these experiments only 1 light intensity level was tested $\left(13.05 \mu \mathrm{E} \mathrm{m}^{-2} \mathrm{~s}^{-1}\right.$ at $12{ }^{\circ} \mathrm{C}, 14.4 \mu \mathrm{E} \mathrm{m}^{-2} \mathrm{~s}^{-1}$ at $22.5^{\circ} \mathrm{C}$ ) and compared with dark controls.

General procedure for endogenous rhythm experiment. For the endogenous feeding rhythm experiment, a predawn plankton sample was collected from the surface of the Skidaway River estuary, Georgia, USA. The sample was taken to a temperature-controlled room and aerated in darkness until dawn (field and laboratory water temperature and salinity $=22.5^{\circ} \mathrm{C}$, $26 \%$ ). At dawn the lights were turned on and 15 adult female Acartia tonsa were sorted into each of 16 jars (volume $=960 \mathrm{ml}$ ) containing 1 to $1.5 \mathrm{~mm}^{3} 1^{-1}$ food (Thalassiosira weissflogii in log growth phase). The jars were rotated on a Ferris wheel at $0.5 \mathrm{rpm}$.

At sunset the lights of the control room were turned off; the copepods were left in darkness for the duration of the experiment. At this time the food concentration of each jar was raised to $1.5 \mathrm{~mm}^{3} \mathrm{l}^{-1}$ with the aid of Coulter Counter ${ }^{\circledR}$ Model TAII and the 31 h experiment was started. The food level was raised to $1.5 \mathrm{~mm}^{3} \mathrm{l}^{-1}$ in each jar every 2 to $4.5 \mathrm{~h}$. The final addition of food to each jar was done at least $2 \mathrm{~h}$ before that jar was removed and its contents were filtered onto a $4.25 \mathrm{~cm}$ Whatman No. 1 paper filter and frozen. The food concentration did not go below $1.2 \mathrm{~mm}^{3} 1^{-1}$ except once, when it fell from 1.5 to $1.0 \mathrm{~mm}^{3} \mathrm{l}^{-1}$ during a $3 \mathrm{~h}$ period in 1 jar (1300 h, November 22, 1985). Thus, food never became limiting. The frozen samples were analyzed using the techniques described for the light experiments. The experiment was designed to allow duplicate estimates of gut fullness every $4 \mathrm{~h}$.

General field procedures. A 96 h field study was conducted to describe temporal changes in the gut fullness of adult female Acartia tonsa in the Newport River estuary, Beaufort, North Carolina, USA. The field site, described by Stearns (1983), was located just off the dock of the Duke University Marine Laboratory, east Pivers Island, in the Beaufort Channel. An anchored boat served as a fixed sampling platform. During the study, bihourly vertical profiles were obtained of adult female $A$. tonsa gut fullness, $4 \pi$ quantal light intensity, chlorophyli $a$ and pheopigment a concentrations and adult $A$. tonsa concentrations.

Plankton samples were collected using centrifugal pumps described by Stearns (1983). Intake hoses were positioned just beneath the surface, at $1.5 \mathrm{~m}$ depth and 
$6.5 \mathrm{~cm}$ above the bottom (1.7 to $3.2 \mathrm{~m}$ ). Zooplankton were sampled at all 3 depths simultaneously using 3 pumps and 3 nets $(0.158 \mathrm{~mm}$ mesh). Triplicate samples at each depth were collected within 12 min using 9 nets and sequential sampling (sampling interval $=$ $4 \mathrm{~min}$. These samples were collected in $125 \mathrm{ml}$ jars and immediately preserved by adding, to each jar, approximately $10 \mathrm{ml}$ of $37.4 \%$ formaldehyde solution buffered with borax and mixed with the vital stain Rose Bengal. Light intensity (spectral range $=400$ to $700 \mathrm{~nm}$ ) was simultaneously measured with a LI-COR 193S spherical quantum sensor fitted with either the sensitive $192 \mathrm{M}$ module or the less sensitive 190M module.

The pumps were also used to collect water samples and additional plankton for gut fullness measurements. For in situ pigment measurements, duplicate $25 \mathrm{ml}$ samples were collected from each depth and filtered separately through a Gelman Type A/E glass fiber filter using a $25 \mathrm{~mm}$ Millipore filtration apparatus. Each filter was treated with $\mathrm{MgCO}_{3}$ and immediately frozen for later analysis of chlorophyll a and pheopigment a concentrations. In situ chlorophyll $a$ and pheopigment a concentrations were used as indicators of available food, as suggested by Boyd et al. (1980). Each sample was analyzed by fluorescence (Strickland \& Parsons 1972) and a Turner Designs fluorometer (Model 10 series). For the gut fullness measurements, copepods were collected from each depth simultaneously using 3 pumps and 3 nets fitted with clean $125 \mathrm{ml}$ jars. Each sample was filtered onto a Whatman No. 1 paper filter, placed in a plastic Petri dish and immediately frozen for later analysis of gut fullness.

The frozen copepod samples were analyzed for chlorophyll $a$ and pheopigment a concentrations per copepod, using the general gut fluorescence technique described earlier. Females were chosen for gut fullness data because they are larger and ingest more than males. At least 9 copepods were selected for each sample.

General statistical procedures. For statistical analyses of the field data, depth was divided into 3 categories according to depth sampled: surface (just beneath the surface), mid-depth $(1.5 \mathrm{~m})$ and bottom $(6.5 \mathrm{~cm}$ above the 1.7 to $3.2 \mathrm{~m}$ bottom). Day/night phases were divided according to light measurements. Quantal light intensities of $1.98 \mu \mathrm{E} \mathrm{m}^{-2} \mathrm{~s}^{-1}$ or less could not be read using the LI-COR quantum sensor. Day and night stations were considered those at which light greater and less than this value was measured at all depths, respectively. Quantal light intensities

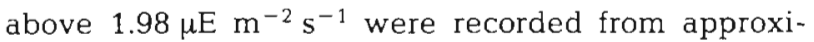
mately $20 \mathrm{~min}$ before sunrise until approximately 20 min after sunset. Every station defined by the quan- tum sensor to be a day station occurred between sunrise and sunset, and every night station occurred between sunset and sunrise.

For Tables 1 and 2, gut fullness data and pigment data were treated similarly. When gut fullness replicates were obtained for a given depth and time, each datum was represented by the mean; otherwise the single sample represented the datum. Each chlorophyll a or pheopigment a datum was the mean of duplicate samples taken at a given depth and time. Data were pooled into appropriate depth $\times$ day/night groups and used to form 2-factor tables. For Fig. 6 and 7, each gut fullness sample defined a datum.

Before any parametric test was used, the data set involved was tested for normality using the Kolmogorov-Smirnov test and for homoscedasticity using Bartlett's test (Sokal \& Rohlf 1981). When significant non-normality or heteroscedasticity was found, an appropriate transformation was performed before the parametric test was done. The parametric tests used included computation of the product-moment correlation coefficient, the Model I, 1-way ANOVA and the Student-Newman-Keuls a posteriori simultaneous testing procedure (Sokal \& Rohlf 1969). Non-significance was determined at $\mathrm{P}>0.05$.

\section{RESULTS}

The light experiments at $14.75^{\circ} \mathrm{C}$ showed a significant negative correlation between light adaptation level and grazing index (Fig. 3). There was no significant correlation between light level and body size ( $\mathrm{r}=$ $0.148 \mathrm{~ns}, \mathrm{n}=51$ ) and the grazing rate was normalized for copepod cephalothorax length. The correlation in Fig. 3 was therefore not the result of copepod size differences at different adaptation intensities. Although feeding decreased at higher light intensities, feeding was not completely inhibited, shown by comparing the grazing index values of copepods exposed to food at high light levels with those treated similarly in the absence of food (Fig. 3).

Although the correlation between light and grazing was significant, there was a relatively low coefficient of determination $\left(r^{2}=0.48, n=51\right)$, which is a measure of the proportion of the variation of the grazing index determined by the variation of the light intensity. Data subsets were selected to minimize variance due to a possible endogenous feeding rhythm and variance due to seasonal or field temperature-related factors. When only data collected between $3.5 \mathrm{~h}$ after sunrise and $3.5 \mathrm{~h}$ before sunset were analyzed, the resulting coefficient of determination was slightly higher $\left(r^{2}=0.50, n=29\right)$. When subsets from this mid-day data set were chosen to restrict the field tem- 


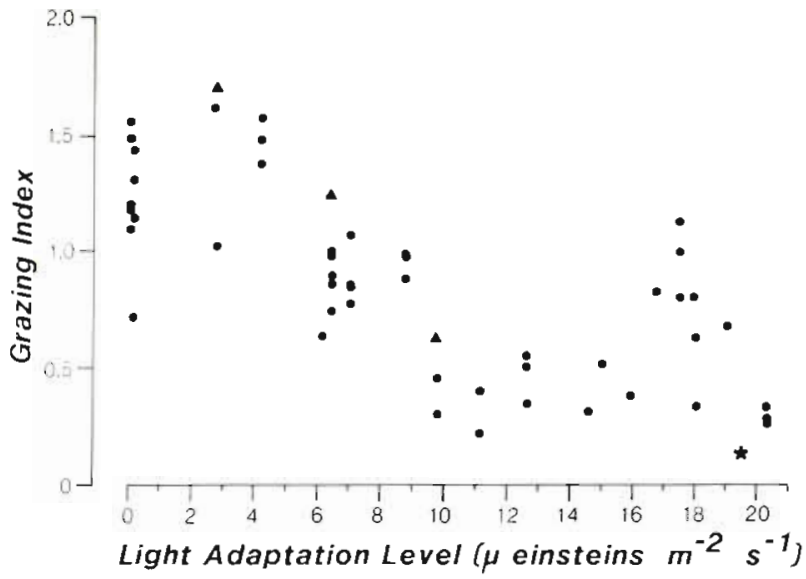

Fig. 3. Acartia tonsa. Grazing index of adult females measured at different light adaptation levels at $14.75^{\circ} \mathrm{C}(\mathrm{r}=$ $-0.69, \mathrm{P}<0.001, \mathrm{n}=51, \mathrm{r}^{2}=0.48$ ). Grazing index is defined by the ratio of pigment concentration (chlorophyll a + pheopigment $a$ in ng copepod $^{-1}$ ) and cephalothorax length in $\mathrm{mm}$ after the ratio calculated for copepods starved for $40 \mathrm{~h}$ has been subtracted. ( $\bullet$ ) Measurements made between sunrise and sunset; ( 1 ) measurements made shortly after sunset; (*) mean index value for copepods treated similarly but without addition of food to test chamber (mean $=0.13 \mathrm{ng}$ pigment copepod ${ }^{-1} \mathrm{~mm}^{-1}, \mathrm{SE}=0.007, \mathrm{n}=6$, light adaptation intensity $\left.=19.6 \mu \mathrm{E} \mathrm{m}^{-2} \mathrm{~s}^{-1}\right)$

perature range, there were large increases in the coefficient of determination (temperature range $=13$ to $16.5^{\circ} \mathrm{C}, \mathrm{r}^{2}=0.74, \mathrm{n}=12$; temperature range $=20$ to $25^{\circ} \mathrm{C}, \mathrm{r}^{2}=0.72, \mathrm{n}=9$ ). (The field temperature range between 16.5 and $20^{\circ} \mathrm{C}$ was not included in this analysis because the light intensities tested were too similar to test for a light effect within this range.) These results indicate the importance of light in affecting feeding behavior, especially evident when variance due to other factors is reduced.

The light experiment at $12^{\circ} \mathrm{C}$ showed a significantly higher grazing index of Acartia tonsa in darkness than when exposed to $13.05 \mu \mathrm{E} \mathrm{m}^{-2} \mathrm{~s}^{-1}$ (mean $_{\text {darkness }}=0.64$, $\mathrm{SE}=0.060, \mathrm{n}=7 ; \operatorname{mean}_{\text {light }}=0.45, \mathrm{SE}=0.022$, $\mathrm{n}=9$; Model I, 1-way ANOVA: $\mathrm{F}_{\mathrm{s}}=10.38, \mathrm{P}<0.01$, $\mathrm{df}=1,14)$. Similar results were found in the $22.5^{\circ} \mathrm{C}$ experiment comparing grazing indices in light $\left(14.4 \mu \mathrm{E} \mathrm{m}^{-2} \mathrm{~s}^{-1}\right)$ and darkness (mean darkness $=1.67, \mathrm{SE}$ $0.239, \mathrm{n}=5 ;$ mean $_{\text {light }}=0.94, \mathrm{SE}=0.208, \mathrm{n}=6$; Model $I_{1} \quad 1$-way ANOVA: $F_{s}=5.34, \quad \mathrm{P}<0.05$, $\mathrm{df}=1,9)$.

An endogenous feeding rhythm in constant darkness was found for Acartia tonsa (Fig. 4). Gut fullness was higher at night than during the day.

Acartia tonsa is a nocturnal feeder in the field (Fig. 5). While depth did not significantly affect gut fullness, there was a definite day/night effect, with significantly fuller guts at night, regardless of depth (Fig. 5, Table 1). The water samples contained higher concentrations of chlorophyll a, pheopigment a or combined pigments near the bottom than at the surface, regardless of the time of day (Table 2). This depth effect became statistically significant for pheopigment $a$ and combined pigments. At each depth, there was almost always a higher pigment concentration during the day than at night, and this difference occasionally became statistically significant (Table 2). Copepod gut fullness and in situ concentrations of chlorophyll $a_{\text {, }}$ pheopigment $a$ and combined pigments were not significantly correlated (Fig, 6). However, there was a significant negative correlation between quantal intensity and gut fullness (Fig. 7).

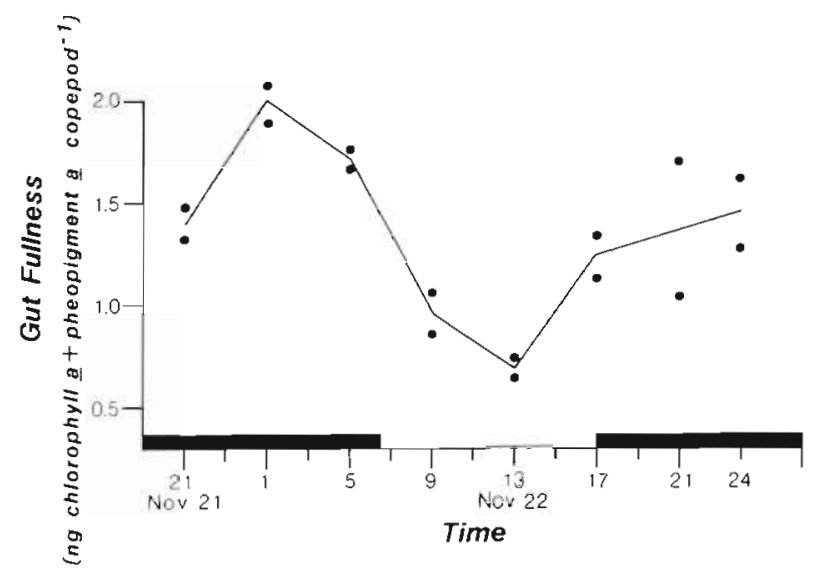

Fig. 4. Acartia tonsa. Endogenous feeding rhythm of adult females under conditions of constant temperature $\left(22.5^{\circ} \mathrm{C}\right)$ and darkness, Nov 21-22, 1985. Food (Thalassiosira weissflogii) was added periodically to keep the food concentration near $1.5 \mathrm{~mm}^{3} \mathrm{1}^{-1}$. Time in hours (Eastern Standard Time) Shaded bars: external hours of darkness. All data are shown means are connected

Fig. 5 shows diel periodicities in the surface abundance of Acartia tonsa indicative of nocturnal vertical migration. Fig. 8 shows nocturnal upward shifts in the vertical distribution of the species. Although the deepest intake hose was positioned only $6.5 \mathrm{~cm}$ from the bottom, the grand mean total concentration of $A$. tonsa in the water column (the sum of the mean concentrations at all 3 depths were $n=3$ concentrations measured per depth per station, averaged across either all day or all night stations) was significantly higher at night (mean $=499$ copepods $\mathrm{m}^{-3}, \mathrm{SE}=77.1, \mathrm{n}=27$ night stations) than during the day (mean $=123$ copepods $\mathrm{m}^{-3}, \mathrm{SE}=27.9, \mathrm{n}=21$ day stations). This result (Model I, 1-way ANOVA, $F_{s}=39.79, P<0.001$, df $=1,46, \log$-transformed data), when combined with the results of 5 other field studies in this estuary (Stearns 1983), indicates that most of the copepods remain on or very close to the bottom of the estuary during the day. 


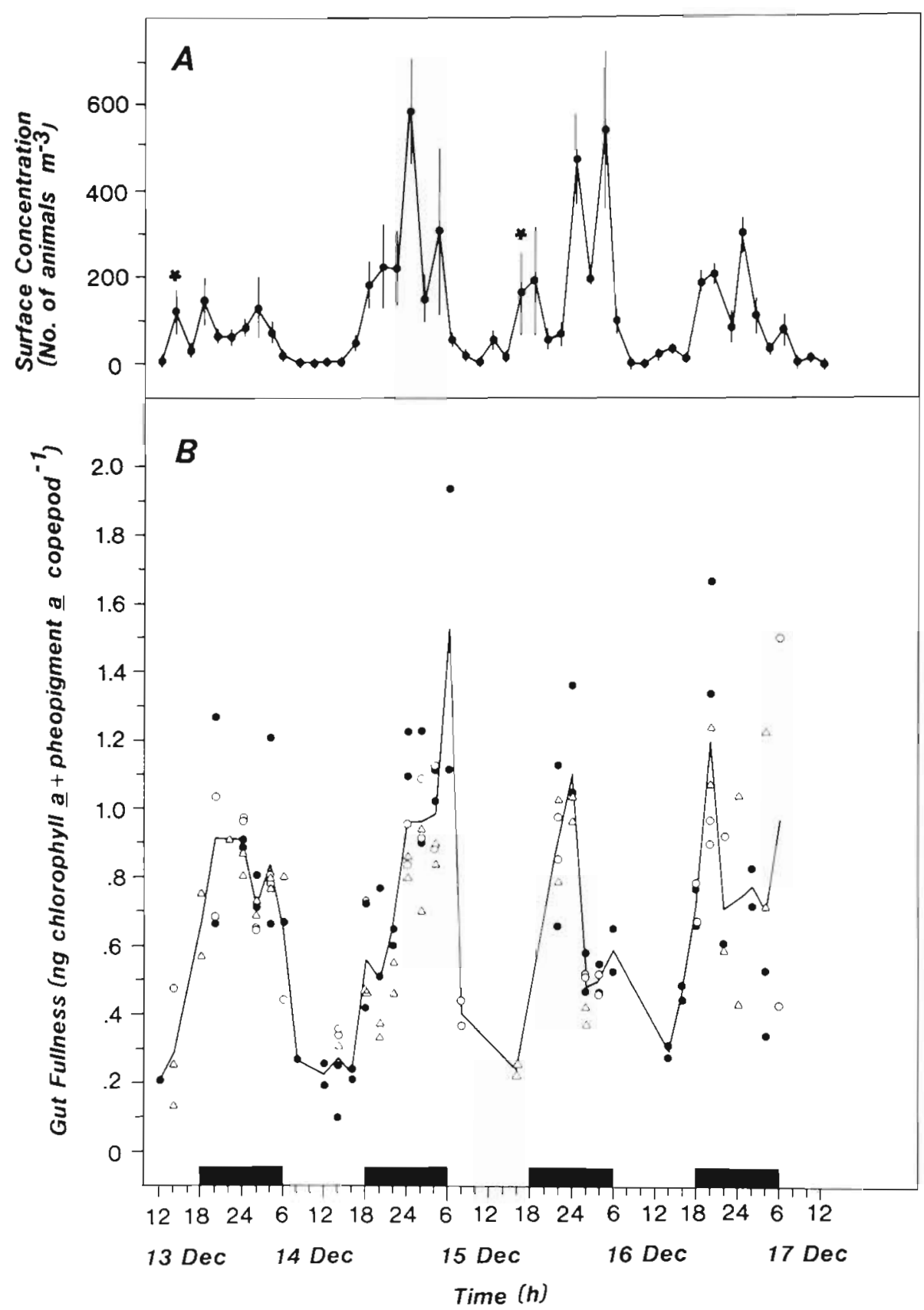

Fig. 5. Acartia tonsa. Field study in the Newport River estuary, North Carolina, USA, December 13 to 17,1978 . Temporal changes in (A) surface concentration of adults (mean \pm standard error, $\mathrm{n}=3$ ) and (B) gut fullness of adult females (ng chlorophyll $a+$ pheopigment $a$ copepod $^{-1}$ ) at 3 depths $([\Delta]$ surface; [ $1.5 \mathrm{~m} ;[0]$ $6.5 \mathrm{~cm}$ above bottom), with mean gut fullness values calculated after pooling across depths and graphed. Time in hours (Eastern Standard Time). Dark bars: dark sampling stations. ( $\star$ ) Transient daytime increase in surface concentration resulting from a local eddy current at that time (Stearns 1983)

\section{DISCUSSION}

Although adult Acartia tonsa is a nocturnal grazer and a nocturnal vertical migrator in very weakly vertically stratified food environments, field results do not support Gauld's (1953) hypothesis that nocturnal grazing results from noctumal vertical migration into a food-rich layer. Plenty of food is present throughout the water column. During the day, most of the copepods are near the bottom of the Newport River estuary, where and when chlorophyll $a$ and pheopigment $a$ concentrations are highest. Thus, relatively low levels of feeding during the day cannot be explained by relatively low food concentrations. There is also no significant effect of depth on gut fullness nor are there significant correlations between gut fullness and in situ concentrations of chlorophyll $a$, pheopigment $a$ and combined pigments.

Fig. 5 and Table 1 do show a tendency for copepod gut fullness to be greater near the bottom during the day when compared with the other 2 depths. This tendency was not due to higher food concentration near the bottom, because the same situation was not observed at night when food concentrations were also 
Table 1. Acartia tonsa. Analysis of 2-way table for spatiotemporal effects on gut fullness of adult females (ng chlorophyll a + pheopigment a copepod ${ }^{-1}$ ) in the Newport River estuary, North Carolina, USA, Dec 13 to 17, 1978. Tests for depth effect on gut fullness during the day, depth effect on gut fullness at night and day/night effect on gut fullness pooled across depth. SE: standard error of the mean; $n$ : sample size; df: degrees of freedom; 1-ANOVA: Model I, 1-way analysis of variance; ${ }^{\cdot} \mathrm{P}<0.001 ;$ $\mathrm{F}_{\mathrm{s}}$ : F statistic; ns: not significant $(\mathrm{P}>0.05)$

\begin{tabular}{|c|c|c|c|c|c|c|c|c|}
\hline \multirow[t]{2}{*}{ Depth } & \multicolumn{4}{|c|}{$\begin{array}{c}\text { Gut fullness } \\
\text { (ng pigment copepod }{ }^{-1} \text { ) }\end{array}$} & \multirow[t]{2}{*}{ Test } & \multirow[t]{2}{*}{ Method } & \multirow[t]{2}{*}{ Result $_{\text {; statistic }}$} & \multirow[t]{2}{*}{ df } \\
\hline & $\begin{array}{c}\text { Day } \\
\text { Mean } \pm \mathrm{SE}\end{array}$ & (n) & $\begin{array}{c}\text { Night } \\
\text { Mean } \pm \mathrm{SE}\end{array}$ & $(n)$ & & & & \\
\hline Surface & $0.25 \pm 0.035$ & (3) & $0.76 \pm 0.048$ & (19) & $\begin{array}{l}\text { Depth effect; } \\
\text { day samples }\end{array}$ & 1-ANOVA & $\begin{array}{l}\text { Sur }=\mathrm{Mid}=\mathrm{Bot} \\
\mathrm{F}_{\mathrm{s}}=3.634 \mathrm{~ns}\end{array}$ & 2,10 \\
\hline Mid-depth & $0.27 \pm 0.037$ & $(7)$ & $0.85 \pm 0.065$ & (22) & $\begin{array}{l}\text { Depth effect; } \\
\text { night samples }\end{array}$ & 1-ANOVA & $\begin{array}{l}\text { Sur }=\text { Mid }=\text { Bot; } \\
F_{\mathrm{s}}=0.694 \mathrm{~ns}\end{array}$ & 2,55 \\
\hline Bottom & $0.41 \pm 0.036$ & (3) & $0.82 \pm 0.047$ & (17) & $\begin{array}{l}\text { Day/night effect; } \\
\text { pooled depths }\end{array}$ & 1-ANOVA & $\begin{array}{l}\text { Night }>\text { Day } \\
F_{\mathrm{s}}=54.269^{\circ}\end{array}$ & 1,69 \\
\hline
\end{tabular}

Table 2. Analyses of 2-way tables for spatiotemporal effects on in situ concentrations $\left(\mu \mathrm{g}^{-1}\right)$ of chlorophyll $a$, pheopigment $a$ and combined pigments in the Newport River estuary, North Carolina, USA, Dec 13 to 17, 1978. Some symbols and tests are defined in Table 1, with additional tests for day/night effects on pigment concentration at the surface, mid-depth and bottom. Da: Day; Ni: Night; SNK: Student-Newman-Keuls Test; $\cdot \mathrm{P}<0.05 ; \mathrm{I}: \log (\mathrm{x}+1)$ transformation

\begin{tabular}{|c|c|c|c|c|c|c|c|}
\hline \multirow[t]{2}{*}{ Pigment } & \multirow[t]{2}{*}{ Depth } & \multicolumn{2}{|c|}{$\begin{array}{l}\text { Pigment concentration } \\
\left(\mu \mathrm{g} \mathrm{l}^{-1}\right)\end{array}$} & \multirow[t]{2}{*}{ Test } & \multirow[t]{2}{*}{ Method } & \multirow[t]{2}{*}{ Result; statistic } & \multirow[t]{2}{*}{$\mathrm{df}$} \\
\hline & & $\begin{array}{l}\text { Day } \\
\text { Mean } \pm S E(n)\end{array}$ & $\begin{array}{l}\text { Night } \\
\text { Mean } \pm \mathrm{SE}(\mathrm{n})\end{array}$ & & & & \\
\hline \multirow[t]{3}{*}{ Chlorophyll } & Surface & $3.1 \pm 0.18$ & $3.2 \pm 0.13$ & $\begin{array}{l}\text { Depth effect; } \\
\text { day samples }\end{array}$ & 1-ANOVA & $\begin{array}{l}\text { Sur }=\text { Mid }=\text { Bot } \\
\mathrm{F}_{\mathrm{s}}=2.818 \mathrm{~ns}\end{array}$ & 2,60 \\
\hline & Mid-depth & $3.7 \pm 0.21$ & $3.4 \pm 0.16$ & $\begin{array}{l}\text { Depth effect } \\
\text { night samples }\end{array}$ & 1-ANOVA & $\begin{array}{l}\text { Sur }=\text { Mid }=\text { Bot }_{i} \\
\mathrm{~F}_{\mathrm{s}}=1.285 \mathrm{~ns}\end{array}$ & 2,80 \\
\hline & Bottom & $3.7 \pm 0.22$ & $3.5 \pm 0.19$ & $\begin{array}{l}\text { Day/night effect; } \\
\text { pooled depths }\end{array}$ & 1-ANOVA & $\begin{array}{l}\mathrm{Da}=\mathrm{Ni}_{i} \\
\mathrm{~F}_{\mathrm{s}}=0.728 \mathrm{~ns}\end{array}$ & 1,144 \\
\hline \multirow[t]{5}{*}{$\begin{array}{l}\text { Pheo- } \\
\text { pigment a }\end{array}$} & Surface & $1.9 \pm 0.10$ & $1.6 \pm 0.08$ & $\begin{array}{l}\text { Depth effect; } \\
\text { day samples }\end{array}$ & SNK & Sur $=$ Mid $<$ Bot ${ }^{*}$ & 2,60 \\
\hline & Mid-depth & $2.1 \pm 0.12$ & $1.8 \pm 0.12(28)$ & $\begin{array}{l}\text { Depth effect; } \\
\text { night samples }\end{array}$ & SNK & tSur $=\mathrm{Mid}<\mathrm{Bot}^{*}$ & 2,80 \\
\hline & Bottom & $2.5 \pm 0.16$ & $2.3 \pm 0.19$ & $\begin{array}{l}\text { Day/night effect; } \\
\text { surface samples }\end{array}$ & 1-ANOVA & $\begin{array}{l}\mathrm{Da}>\mathrm{Ni}_{i} \\
\mathrm{~F}_{\mathrm{s}}=4.505\end{array}$ & 1,47 \\
\hline & & & & $\begin{array}{l}\text { Day/night effect; } \\
\text { mid-depth samples }\end{array}$ & 1-ANOVA & $\begin{array}{l}\mathrm{Da}>\mathrm{Ni} \\
\mathrm{F}_{5}=4.055\end{array}$ & 1,47 \\
\hline & & & & $\begin{array}{l}\text { Day/night effect; } \\
\text { bottom samples }\end{array}$ & 1-ANOVA & $\begin{array}{l}\mathrm{Da}=\mathrm{Ni} \\
\mathrm{F}_{\mathrm{s}}=1.049 \mathrm{~ns}\end{array}$ & 1,46 \\
\hline \multirow[t]{5}{*}{$\begin{array}{l}\text { Combined } \\
\text { pigments }\end{array}$} & Surface & $5.0 \pm 0.27$ & $4.8 \pm 0.19(28)$ & $\begin{array}{l}\text { Depth effect; } \\
\text { day samples }\end{array}$ & SNK & $\begin{array}{l}\text { Sur }=\text { Mid, Mid }=\text { Bot, } \\
\text { Sur }<\text { bot. }\end{array}$ & 2,60 \\
\hline & Mid-depth & $5.8 \pm 0.30$ & $5.1 \pm 0.27$ & $\begin{array}{l}\text { Depth effect; } \\
\text { night samples }\end{array}$ & SNK & $\begin{array}{l}* \text { Sur }=\text { Mid, Mid }=\text { Bot, } \\
\text { Sur }<\text { bot }\end{array}$ & 2,80 \\
\hline & Bottom & $6.2 \pm 0.35$ & $5.8 \pm 0.34$ & $\begin{array}{l}\text { Day/night effect; } \\
\text { surface samples }\end{array}$ & 1-ANOVA & $\begin{array}{l}\mathrm{Da}=\mathrm{Ni} \\
\mathrm{F}_{\mathrm{s}}=0.324 \mathrm{~ns}\end{array}$ & 1,47 \\
\hline & & & & $\begin{array}{l}\text { Day/night effect: } \\
\text { mid-depth samples }\end{array}$ & 1-ANOVA & $\begin{array}{l}\mathrm{Da}=\mathrm{Ni}_{i} \\
\mathrm{~F}_{\mathrm{s}}=2.589 \mathrm{~ns}\end{array}$ & 1,47 \\
\hline & & & & $\begin{array}{l}\text { Day/night effect } \\
\text { bottom samples }\end{array}$ & 1-ANOVA & $\begin{array}{l}\mathrm{Da}=\mathrm{Ni}_{i} \\
\mathrm{~F}_{\mathrm{s}}=0.767 \mathrm{~ns}\end{array}$ & 1,46 \\
\hline
\end{tabular}




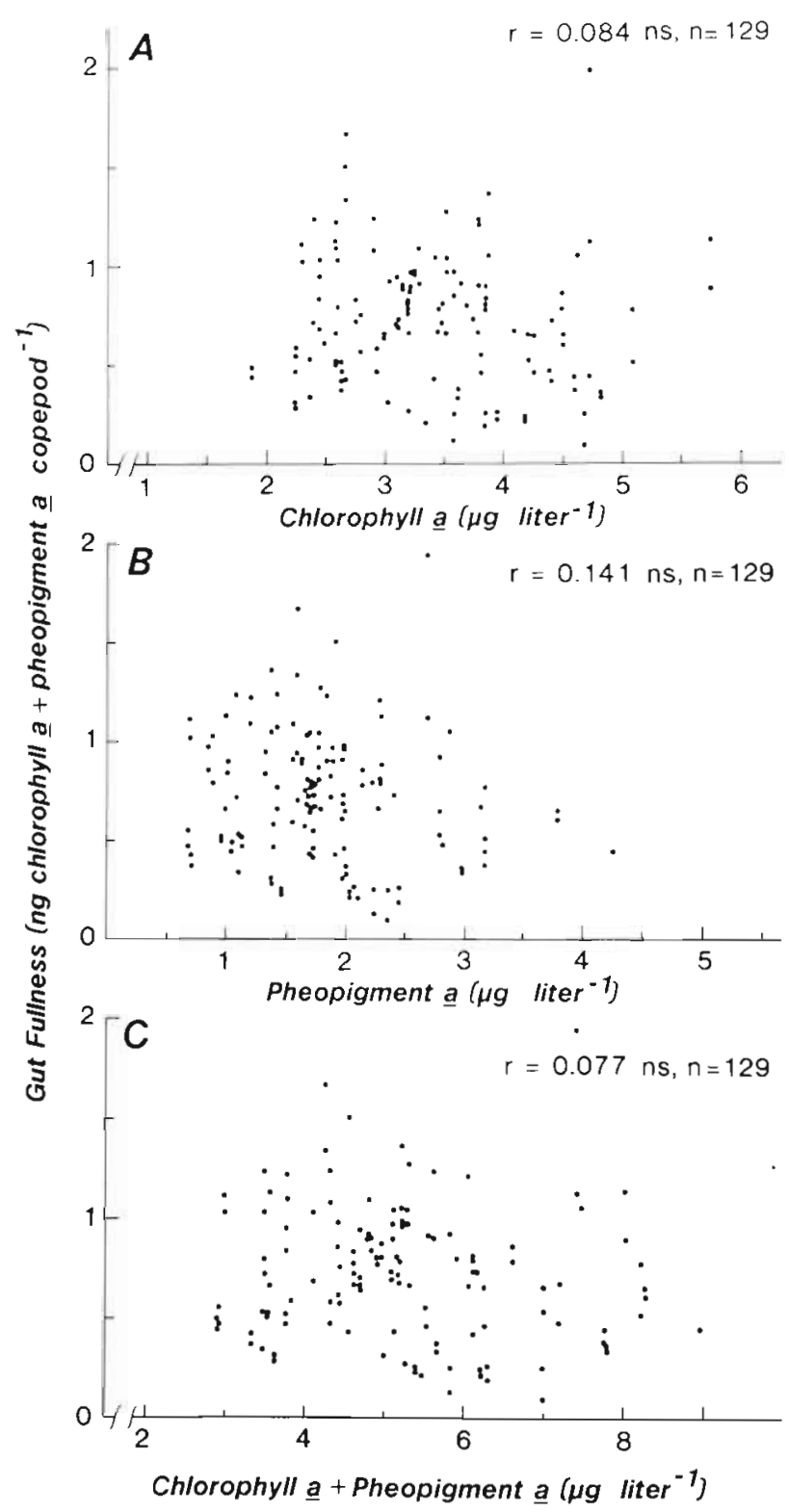

Fig. 6. Acartia tonsa. Field study in the Newport River estuary, North Carolina, USA, December 13 to 17, 1978. Correlations between gut fullness of adult females (ng chlorophyll $a$ + pheopigment $a$ copepod $^{-1}$ ) and (A) chiorophyll $a$, (B) pheopigment $a$ and $(C)$ combined pigment concentrations ( $\mu \mathrm{g}$ $1^{-1}$ ) at the depths where the zooplankton samples were collected. Correlation coefficients are shown

higher near the bottom. Also, food concentration and gut fullness were not correlated (Fig. 6). The tendency toward greater gut fullness with depth during the day may, however, be explained by lower light intensity at depth. During the field study, daytime light intensity near the bottom averaged $16 \%$ of the intensity near the surface (range $=4$ to $30 \%, n=21$ day stations).

The copepods may feed at one depth and then move to another depth where they are captured (see Dagg \& Wyman 1983), so that an association between food

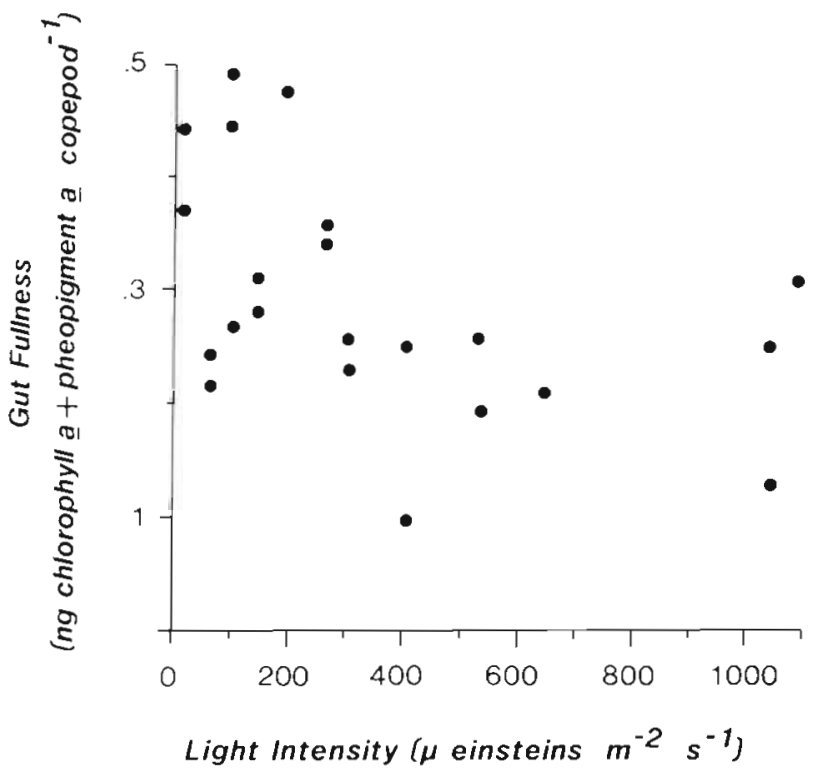

Fig. 7. Acartia tonsa. Field study in the Newport River estuary, North Carolina, USA, December 13 to 17,1978. Correlation between gut fullness of adult females (ng chlorophyll a + pheopigment $a$ copepod $\left.{ }^{-1}\right)$ and quantal intensity $(\mu \mathrm{E}$ $\mathrm{m}^{-2} \mathrm{~s}^{-1}$ ) at depths where zooplankton samples were collected during daylight hours. A significant negative correlation was found $(r=-0.474, \mathrm{P}<0.05, \mathrm{n}=22)$

concentration and gut fullness may not be apparent. Fig. 5 and Table 1, however, show increased feeding at night regardless of the depth of capture.

It is also possible that the species is actually on the bottom of the shallow estuary and mechanically unable to feed during the day, requiring vertical migration to move it off the bottom before feeding can occur (Hart 1977). However, copepods collected well off the bottom during the day still show lower gut fullness values than those collected at night (Fig. 5i Stearns unpubl. data).

The above discussion argues against Gauld's (1953) hypothesis as an explanation of the nocturnal timing of increased grazing by Acartia tonsa. The nocturnal feeding behavior and the significant negative correlation between light intensity and gut fullness in the field support the hypothesis that light controls feeding, either directly or as a Zeitgeber for an endogenous feeding rhythm.

The slight increase in $\mathrm{r}^{2}$ after selecting only data from the middle of the day suggests a possible time-ofday effect on feeding. Although only 3 measurements were made after sunset, each post-sunset grazing index was higher than the other grazing indices measured under the same light conditions during daylight hours (Fig. 3). These findings indicate a possible nocturnal endogenous feeding rhythm. Fig. 4 provides direct evidence for such a rhythm.

The large increases in $r^{2}$ after selecting data within 


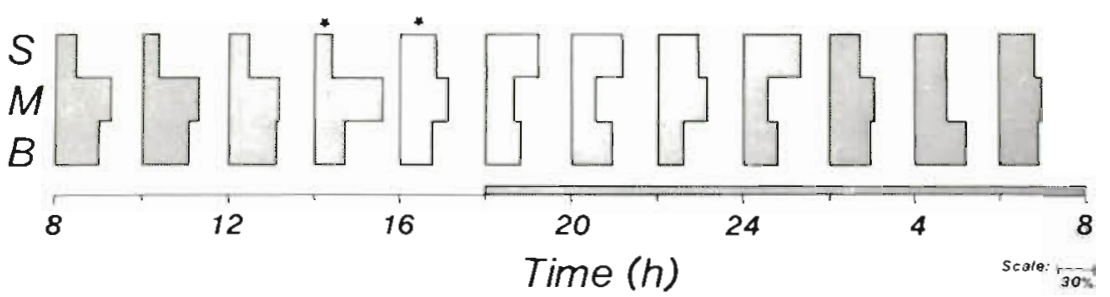

Fig. 8. Acartia tonsa. Field study in the Newport River estuary, North Carolina, USA, December 13 to 17,1978 . Temporal changes in the mean relative vertical distribution of adults. Mean relative vertical distribution was the mean distribution per station hour ( $\mathrm{n}=3$ distributions measured per station hour), averaged over the 4 d period ( $n=4$ or 5 identical station hours during the study). Time in hours (Eastern Standard Time). Dark bar: dark sampling stations; $S$ : surface; $M$ : mid-depth $(1.5 \mathrm{~m})$; B: $6.5 \mathrm{~cm}$ above bottom; $(\star)$ transient daytime upward shift in distribution resulting from a local eddy current (Stearns 1983)

narrow field temperature ranges suggest that copepod grazing depends in part on factors related to field temperature or season. Possible factors are different metabolic rates that do not completely acclimate to the experimental temperature within the allowed period or seasonal differences in reproductive physiology and hence food requirements. Additional research is necessary to determine how these factors affect copepod feeding behavior.

Fig. 3 and the increase in $\mathrm{r}^{2}$ when variance due to non-light factors is minimized provide evidence that light can directly affect feeding behavior in adult female Acartia tonsa. The degree of gut fullness is influenced by the light intensity to which the copepod is adapted at the time of feeding: the higher the light adaptation level, the lower the grazing index. Light may be directly affecting the ingestion rate or it may be affecting the gut evacuation rate which, in turn, affects the rate of ingestion. Copepods adapted to the highest experimental light intensity were still grazing, since their grazing index was higher than that of copepods treated similarly but not offered food (Fig. 3).

Copepods with empty guts show an initial linear increase in gut fullness without defecation when exposed to food (Dagg 1983). It is not known whether Acartia tonsa was still in this filling phase at the time the grazing index was measured experimentally. The actual gut fullness level measured in darkness in the laboratory (mean $=1.19 \mathrm{ng}$ chlorophyll a + pheopigment a copepod ${ }^{-1}, \mathrm{SE}=0.077, \mathrm{n}=5$ ) approximates the mean peak levels found in the field at night (Fig. 5). These nocturnal peaks occurred after several hours of nighttime feeding, suggesting that both the field and the laboratory copepods had been beyond the initial filling phase. The different food concentrations and feeding histories make this comparison no more than suggestive. Further research is needed to understand the effect of light on copepod grazing rates during and after initial filling.

The experimental light intensity range (Fig. 3) occurs near sunrise and sunset in the Newport River estuary (Stearns \& Forward 1984b). Stearns \& Forward (1984b) found that the twilight combination of relative (\%) change in light intensity and light adaptation level directly controls the timing of nocturnal vertical migration in Acartia tonsa. Nocturnal grazing also appears to be timed by twilight cues. Haney \& Hall (1975) provide evidence that diel feeding in Daphnia pulex is timed by relative light change near dawn and dusk. Further research is necessary to determine the specific light cues that time the feeding rhythm of $A$. tonsa. Although copepod feeding appears to be most affected by twilight intensities (Fig. 3), the significant negative correlation between gut fullness and daytime intensities in the field (Fig. 7) suggests that much higher light intensities also influence copepod grazing.

The results presented here offer a reasonable explanation of how light controls the observed nocturnal feeding pattern of Acartia tonsa. Some aspect of light associated with sunset may act directly or as a Zeitgeber to time an increase in feeding at that time. During the night, the light intensity is too low to inhibit feeding effectively and maximal grazing occurs. Near dawn, some aspect of light associated with sunrise may act directly on feeding or may cue an endogenous rhythm and feeding decreases at that time. During the day, light intensity still directly affects grazing, with reduced grazing at higher light levels. Nocturnal grazing is thus timed by light cues and is not the result of nocturnal vertical migration within a vertically stratified food environment.

Acartia tonsa is a food item for potentially visual predators (Thayer et al. 1974, Kjelson et al. 1975, Fulton 1984). There is evidence of a direct relation between the amount of pigmentation in zooplankters and the degree of visual predation (Zaret 1972, Kerfoot 1980, Stenson 1980). Nocturnal feeding may be adaptive by allowing $A$. tonsa to feed and fill its gut with plant pigments when susceptibility to visual predation is minimized.

This research experimentally demonstrates the direct effect of quantal intensity on the grazing 
behavior of a copepod using a simulated, natural underwater ALD. The results show the importance of light in the direct control of grazing and as a possible Zeitgeber for an endogenous feeding rhythm. Although nocturnal grazing and nocturnal vertical migratory behaviors are correlated for Acartia tonsa, they do not appear to be causally related. These findings may explain field reports of nocturnal feeding, including those that cannot be explained by Gauld's (1953) hypothesis of vertical migration within a vertically stratified food environment.

Acknowledgements. The field research done in the Newport River estuary was supported by the Duke University Graduate School under Research Award No. 303-3016 to D. Stearns and by the National Science Foundation under Grant No. OCE8007434 to R. B. Forward Jr, I thank the following people for their field assistance and use of equipment: L. Cahoon, R. B. Forward Jr., J. Harding, M. Pagano, G.-A. Paffenhöfer, L. Pomeroy, J. Ramus, B. Sherman and J. Yoder. I also thank J. Richardson (Savannah State College) for the light sensor used in laboratory measurements, as well as E. Head, D. Menzel, G.-A. Paffenhöfer, H. Price and 2 anonymous reviewers for constructive criticism of the manuscript. The manuscript was typed by D. McCauley. The figures were prepared by A. Boyette and S. McIntosh. This article is dedicated to Margery Slife Stearns.

\section{LITERATURE CITED}

Arashkevich, Ye. G. (1975). Duration of digestion in marine copepods. Tr. Inst. Okeanol. im. P. P. Shirshova 102: 351-357 (Dep. Environ. Fish. Mar. Ser. Can. Transl. Ser. 3598 , p. 1-13)

Autrum, H. (1981). Light and dark adaptation in invertebrates. In: Autrum, H. (ed.) Handbook of sensory physiology, Vol. VII, Part 6. Comparative physiology and evolution of vision in invertebrates. C. Invertebrate visual centers and behavior II. Springer-Verlag, New York, p. 1-91

Baars, M. A., Oosterhuis, S. S. (1984). Diurnal feeding rhythms in North Sea copepods measured by gut fluorescence, digestive enzyme activity and grazing on labelled food. Neth. J. Sea Res. 18: 97-119

Båmstedt, U. (1984). Diel variations in the nutritional physiology of Calanus glacialis from Lat. $78^{\circ} \mathrm{N}$ in the summer. Mar. Biol. 79: 257-267

Boyd, C. M., Smith, S. L., Cowles, T. J. (1980). Grazing patterns of copepods in the upwelling system off Peru. Limnol. Oceanogr. 25: 583-596

Buchanan, C., Goldberg, B., McCartney, R. (1982). A laboratory method for studying zooplankton swimming behaviors. Hydrobiologia 94: 77-89

Conover, R. J. (1981). Nutritional strategies for feeding on small suspended particles. In: Longhurst, A. (ed.) Analysis of marine ecosystems. Academic Press, London, p. $363-395$

Cowles, T. J. (1977). Copepod feeding in the Peru upwelling system. Ph.D. thesis, Department of Zoology, Duke University, Durham, North Carolina

Dagg, M. J. (1983). A method for the determination of copepod feeding rates during short time intervals. Mar. Biol. 75: 63-67
Dagg, M. J., Grill, D. W. (1980). Natural feeding rates of Centropages typicus females in the New York Bight. Limnol. Oceanogr 25: 597-609

Dagg, M. J., Wyman, K. D. (1983). Natural ingestion rates of the copepods Neocalanus plumchrus and $N$. cristatus calculated from gut contents. Mar. Ecol. Prog. Ser. 13: 37-46

Daro, M. H. (1980). Field study of the diel feeding of a population of Calanus finmarchicus at the end of a phytoplankton bloom, FLEX '76, 22 May-5 June. Meteor Forsch.-Ergebnisse A, 22, 123-132

Duval, W. S., Geen, G. H. (1976). Diel feeding and respiration rhythms in zooplankton. Limnol. Oceanogr. 21: 823-829

Fernández, F. (1977). Efecto de la intensidad de luz natural en la actividad metabólica y en la alimentación de varias especies de copépodos planctónicos. Investigación pesq 41: 575-602

Fuller, J. L. (1937). The feeding rate of Calanus finmarchicus in relation to environmental conditions. Biol. Bull. mar. biol. Lab., Woods Hole 72: 233-246

Fulton, R. S. III. (1984). Predation, production and the organization of an estuarine copepod community. J. Plankton Res. 6: 399-415

Gauld, D. T. (1953). Diurnal variation in the grazing of planktonic copepods. J. mar. biol. Ass. U.K. 31: 461-474

Haney, J. F., Hall, D. J. (1975). Diel vertical migration and filter-feeding activities of Daphnia. Arch. Hydrobiol. 75: 413-441

Hart, R. C. (1977). Feeding rhythmicity in a migratory copepod (Pseudodiaptomus hessei (Mrázek)). Freshwat. Biol. 7: $1-8$

Hayward, T. L. (1980). Spatial and temporal feeding patterns of copepods from the North Pacific central gyre. Mar. Biol. 58: 295-309

Head, E. J. H., Harris, L. R., Abou Debs, C. (1985). Effect of daylength and food concentration on in situ diumal feeding rhythms in Arctic copepods. Mar. Ecol. Prog. Ser. 24: 281-288

Head, E. J. H., Wang, R, Conover, R. J. (1984). Comparison of diurnal feeding rhythms in Temora longicornis and Centropages hamatus with digestive enzyme activity. J. Plankton Res. 6: 543-551

Kerfoot, W. C. (1980). Commentary: transparency, body size and prey conspicuousness. In: Kerfoot, W. C. (ed.) Evolution and ecology of zooplankton communities. University Press of New England, Hanover, New Hampshire, p. $609-617$

Kjelson, M. A., Peters, D. S., Thayer, G. W., Johnson, G. N. (1975). The general feeding ecology of postlarval fishes in the Newport River estuary. U.S. Nat. Mar. Fish. Serv. Bull. 73: $137-144$

Kleppel, G. S., Manzanilla, E. (1983). Analyses of feeding in two marine copepods from Santa Monica Bay, California. Fish. Bull. U.S. 81: 154-161

Kleppel, G. S., Willbanks, L., Pieper, R. E. (1985). Diel variation in body carotenoid content and feeding activity in marine zooplankton assemblages. J. Plankton Res. 7: 569-580

Mackas, D., Bohrer, R. (1976). Fluorescence analysis of zooplankton gut contents and an investigation of diel feeding patterns. J. exp. mar. Biol. Ecol. 25: 77-85

Marshall, S. M. (1924). The food of Calanus finmarchicus during 1923. J. mar. biol. Ass. U.K. 13: 473-479

Marshall, S. M., Orr, A. P. (1955). On the biology of Calanus finmarchicus. VIII. Food uptake, assimilation and excretion in adult and Stage $\mathrm{V}$ Calanus. J. mar. biol. Ass. U.K. 34: 495-529

Mayzaud, O., Mayzaud, P., de la Bigne, C., Grohan, P. (1984). 
Diel changes in the particulate environment, feeding activity and digestive enzyme concentration in neritic zooplankton. J. exp. mar. Biol. Ecol. 84: 15-35

McAllister, C. D. (1971). Some aspects of nocturnal and continuous grazing by planktonic herbivores in relation to production studies. Fish. Res. Bd Can. Tech. Rep. 248: $1-281$

McAllister, C. D. (1973). Zooplankton rations, phytoplankton mortality and the estimation of marine production. In: Steele, J. H. (ed.) Marine food chains. Oliver and Boyd, Edinburgh, p. 419-457

Nicolajsen, H., Møhlenberg, F., Kiørboe, T. (1983). Algal grazing by the planktonic copepods Centropages hamatus and Pseudocalanus sp.: diurnal and seasonal variation during the spring phytoplankton bloom in the Øresund. Ophelia 22: 15-31

Peruyeva, Ye. G (1977). Diurnal feeding rhythm of IV copepodite stage of Calanus glacialis Jaschnov. Oceanology 17 . $719-721$

Petipa, T. S. (1958). The diurnal feeding rhythm of the copepod crustacean Acartia clausi Giesbr. Dokl. Akad. Nauk SSSR 120: 435-437

Petipa, T. S. (1964a). Diurnal rhythm of the consumption and accumulation of fat in Calamus helgolandicus (Claus) in the Black Sea. Dokl. Akad. Nauk SSSR 156: 1440-1443. (Dokl. Biol. Sci. [English Transl.] 156: 361-364)

Petipa, T S. (1964b). Diurnal rhythm in feeding and daily ration of Calanus helgolandicus (Claus) in the Black Sea. Trudy Sevastopol. biol. Sta. 15: 69-93

Petipa, T. S., Makarova, N. P. (1969). Dependence of phytoplankton production on rhythm and rate of elimination. Mar. Biol. 3: 191-195

Richman, S., Rogers, J. N. (1969). The feeding of Calanus helgolandicus on synchronously growing populations of the marine diatom Ditylum brightwellii. Limnol. Oceanogr. 14: 701-709

Schallek, W. (1942). The vertical migration of the copepod Acartia tonsa under controlled illumination. Biol. Bull. mar. biol. Lab., Woods Hole 82: 112-126

Schallek, W. (1943). The reaction of certain Crustacea to direct and to diffuse light. Biol. Bull. mar. biol. Lab., Woods Hole 84: 98-105

Simard, Y., Lacroix, G., Legendre, L. (1985). In situ twilight grazing rhythm during diel vertical migrations of a scattering layer of Calanus finmarchicus. Limnol. Oceanogr. 30: 598-606

Sokal, R. R., Rohlf, F. J. (1969). Biometry. W. H. Freeman and Co., San Francisco

Sokal, R. R., Rohif, F. J. (1981). Biometry, 2nd ed. W. H. Freeman and Co., New York
Stearns, D. E. (1983). Control of nocturnal vertical migration in the calanoid copepod Acartia tonsa Dana in the Newport River estuary, North Carolina. Ph.D. thesis, Department of Zoology, Duke University, Durham, North Carolina

Stearns, D. E., Forward, R. B. Jr. (1984a). Photosensitivity of the calanoid copepod Acartia tonsa. Mar. Biol. 82: 85-89

Stearns, D. E., Forward, R. B. Jr, (1984b). Copepod photobehavior in a simulated natural light environment and its relation to nocturnal vertical migration. Mar. Biol. 82: 91-100

Stenson, J. A. E. (1980). Predation pressure from fish on two Chaoborus species as related to their visibility. In: Kerfoot, W. C. (ed.) Evolution and ecology of zooplankton communities. University Press of New England, Hanover, New Hampshire, p. 618-622

Strickland, J. D. H., Parsons, T. R. (1972). A practical handbook of seawater analysis ( $2 \mathrm{nd}$ ed.). Bull. Fish Res. Bd Can. 167

Sushkina, A. P. (1962). Vertical migration and circadian feeding rhythm of Calanus finmarchicus (Gunn.) in relation to age and fat content. Trudy vses. nauchno-Issled. Inst. morsk. ryb. khoz. Okeanogr. 46: 235-253

Tande, K. S., Slagstad, D. (1982). Ecological investigation on the zooplankton community of Balsfjorden, northern Norway. Seasonal and short-time variations in enzyme activity in copepodite stage V and VI males and females of Calanus finmarchicus (Gunnerus). Sarsia 67: 63-68

Thayer, G. W., Hoss, D. E., Kjelson, M. A., Hettler, W. F. Jr. Lacroix, M. W. (1974). Biomass of zooplankton in the Newport River estuary and the influence of postlarval fishes. Chesapeake Sci. 15: 9-16

Turner, J. T. (1984a). Zooplankton feeding ecology: contents of fecal pellets of the copepods Acartia tonsa and Labidocera aestiva from continental shelf waters near the mouth of the Mississippi River. P.S.Z.N.I.: Mar. Ecol. 5: 265-282

Turner, J. T. (1984b). The feeding ecology of some zooplankters that are important prey items of larval fish. NOAA Tech. Rep. NMFS 7: 1-28

Yentsch, C., Menzel, D. (1963). A method for the determination of phytoplankton chlorophyll and phaeophytin by fluorescence. Deep Sea Res. 10: 221-231

Zagorodnyaya, Y. A. (1974). Feeding habits and migration of the Black Sea copepod Pseudocalanus elongatus (Boek) in winter. Hydrobiol. J. 10: 35-41

Zaret, T.M. (1972). Predators, invisible prey, and the nature of polymorphism in the Cladocera (Class Crustacea). Limnol. Oceanogr. 17: 171-184 